\title{
Modes of Combinative Innovation: Case of Samsung Electronics
}

\author{
Yoo Soo Hong*
}

Published Online Date: November 1, 2012

\begin{abstract}
In this age of convergence, a combinative nature of innovation is in need of revisiting. The innovation based on combination is named "combinative innovation" and defined operationally as the innovation that combines different modes of combinations. Five modes are characterized and the framework is applied to the case of CDMA mobile phone development of Samsung Electronics Company in the 1990s. The case study demonstrates the usefulness of the framework and the future direction of further elaboration of the framework.
\end{abstract}

Keywords Combinative innovation, combination modes, digital convergence, Samsung electronics

\section{Introduction}

Innovation is a result of combination. In this age of convergence and fusion, it is more so. As the areas of business and technology are expanding and becoming complex, previously un-related industries and technologies tend to be combined and integrated. Since there are many different ways to combine factors and accordingly make outcomes differ, how to combine these seemingly or previously un-related areas is crucial for the success of innovation and business. Clear understanding and a careful choice of combination methods are very important especially for combinatory innovation. However, the exiting literature on innovation is not satisfactory since there is a wide gap between the need and fulfillment.

The purpose of the paper is to fill in the gap of the literature by introducing a conceptual categorization of combination modes in innovation, developing an analytical framework on the bases of the modes, and applying the analytical

\footnotetext{
* Director and senior economist, Institute for Global Innovation and Development, Seoul, Korea (yooshong@gmail.com). The author would like to thank two anonymous referees for their helpful comments on the earlier version of this paper.
} 
framework to a case study. Although the areas of innovation include innovations in material, production process, product, distribution, and organization (Schumpeter, 1934; 1980), only technological innovation (i.e. product innovation and process innovation) is treated in this paper due to space constraint. The main purpose of the paper is not to thoroughly deal with different areas but to attempt to elaborate combinative innovation and to show its usefulness. The essential features of the paper, focused on technological innovation, can be easily extended to all the five areas of innovation.

The main body of this paper is structured by two parts: analytical framework and a case study. For the analytical framework, firstly combinatory innovation is defined. Then five kinds of modes of combination are conceptualized with respective characteristics. Lastly, the management and measurement methods of each of the combinative modes are discussed. The second part is a case study. The analytical framework is applied to the innovation of the first digital (CDMA-based) mobile phone product of Samsung Electronics Company (hereafter, Samsung Electronics or SEC or Samsung) to verify the usefulness of the framework. The case was chosen because it is an architectural innovation (Garcia and Calantone, 2002) that has many interesting characteristics and implications and it reflects the age of digital convergence in Korea.

\section{Analytical Framework}

\subsection{Concepts}

Schumpeter (1980: 65) views innovation as a new combination: "To produce other things, or the same things by a different method, means to combine these materials and forces differently...Development in our sense is then defined by the carrying out of new combinations." Although it is Schumpeter who emphasized the nature of combining innovation, in recent periods it is Kogut and Udo (1992) who remarked: "Creating new knowledge does not occur in abstraction from current abilities. Rather, new learning, such as innovations, is products of firm's combinative capabilities to generate new applications from existing knowledge. By combinative capabilities, we mean the intersection of the capability of the firm to exploit its knowledge and the unexplored potential of the technology."

Today numerous kinds of innovations are conceptualized for the theoretical or practical purpose: to name a few, revolutionary innovation, evolutionary (incremental) innovation, product innovation, process innovation, architectural innovation, modular innovation, disruptive innovation, sustaining innovation, market-pull innovation, technology-push innovation, and so on. 
However, in this age of technological convergence, we need a new concept of innovation which can better capture the convergence phenomena (Wang and Peng, 2008). I think one of the candidates is the concept of combinative innovation, which appears in the paper by Alkaersig et al. (2012). Although they have not explicitly defined the concept, they use it to indicate "innovations based on combinations." From the view point of Schumpeter, this may be almost tautological since he views innovation itself as nothing else but a new combination.

In this paper, combinative innovation is defined as the innovation that combines different modes of combinations. This definition will be complete only when the mode of combination is further defined. There are five typical modes of combinations in combinative innovation as summarized in Table 1.

The first dynamic combination is a combination mode dealing with the mix of incremental innovation of present technology (exploitation) and innovation for future technology (exploration) with certain degrees. This is a matter of ambidexterity (Ramachandran and Lengnick-Hall, 2012) in innovation, which means how to weigh the incremental innovation of existing technology and emerging or expected future technology. Because it deals with time-involved decision making, it is coined dynamic combination.

Table 1 Mode of combination in combinative innovation

\begin{tabular}{|l|l|l|}
\hline \multicolumn{1}{|c|}{ Mode } & \multicolumn{1}{|c|}{ Concept } & \multicolumn{1}{c|}{ Characteristics } \\
\hline $\begin{array}{l}\text { Dynamic } \\
\text { combination }\end{array}$ & $\begin{array}{l}\text { - Combining incremental innovation of } \\
\text { present technology (exploitation) and } \\
\text { innovation for future technology } \\
\text { (exploration) with certain degrees. }\end{array}$ & $\begin{array}{l}\text { Exploitation }<-> \\
\text { exploration }\end{array}$ \\
\hline $\begin{array}{l}\text { Open } \\
\text { combination }\end{array}$ & $\begin{array}{l}\text { - Combining technologies acquired from } \\
\text { outside and distributing own technologies } \\
\text { to others for joint utilization }\end{array}$ & $\begin{array}{l}\text { Absorptive }<-> \\
\text { distributive }\end{array}$ \\
\hline $\begin{array}{l}\text { Vertical } \\
\text { combination }\end{array}$ & $\begin{array}{l}\text { - Combining more of downstream } \\
\text { technologies or more of upstream } \\
\text { technologies }\end{array}$ & $\begin{array}{l}\text { Upstream }<-> \\
\text { downstream }\end{array}$ \\
\hline $\begin{array}{l}\text { Functional } \\
\text { combination }\end{array}$ & $\begin{array}{l}\text { - Combining (intensive) functional } \\
\text { improvement of existing technologies and } \\
\text { adding new (extensive) functions to existing } \\
\text { technologies }\end{array}$ & $\begin{array}{l}\text { Intensive <-> } \\
\text { extensive }\end{array}$ \\
\hline $\begin{array}{l}\text { Multiple } \\
\text { combination }\end{array}$ & $\begin{array}{l}\text { - The way managing all combination modes: } \\
\text { synergic or sporadic }\end{array}$ & Synergic <-> sporadic \\
\hline
\end{tabular}

The second open combination is closely related with open innovation. (Rasmussen, 2012; Lakhani, 2012). However, it focuses on the pattern and direction of technological knowledge sharing. The technological knowledge 
obtained from outsiders is absorptive and the owned technological knowledge rendered to outsiders is distributive (Bogers and West, 2011).

The third vertical combination is how to combine vertically divided technologies (for parts and components or intermediate products) including the final product in the process of the innovation of concern. The point here is whether to combine more downstream technologies or more upstream technologies.

The fourth functional combination focuses on the choice of increasing the quality of existing functions of technology (intensive) or adding new functions (extensive). All these four modes of combinations are not mutually independent or exclusive so that they may be overlapping to a certain extent.

The fifth multiple combination is not a unique combination mode like the other four modes, but a combination of the other four modes of combinations. It deals with how to manage other combination modes so that it is a supermode whereas the other four modes are sub-modes. Thus, it is coined as "multiple combination." If the sub-modes are managed to maximize synergy, it is characterized as being synergetic. If it is randomly managed, it is characterized as being sporadic.

\subsection{Analytical Framework}

An innovation usually follows several steps such as goal setting, strategic formulation, input acquisition, process, output acquisition, and evaluation and feedback. There are many kinds of inputs for an innovation such as human resources, capital, technological knowledge, and information. Process consists of many individual or organizational activities such as organizing research teams, meetings, experiments, inventions, tests, proto type development, learning, etc. Outputs are new technologies and knowledge, patents, new products, and so on. An innovation starts with setting goals from the need of the innovation. In order to achieve the goals, strategies are formulated. A strategy is the plan to achieve the best innovation. Effects are the contributions or damages of the innovation to the company's business. The evaluation of these effects is fed back to the next round of goal setting and strategic formulation.

In order to apply the concept of combinative innovation and modes of combinations to the real world situation, operational definitions and measurements for each stage of innovation are needed. In addition, some suggestions are shown in case analysis. For example, resource allocation to each activity involved can be the basis for characterizing input acquisition and process stages. The number of patents is a measure for outputs. The change in market share or profit is a good measure for evaluation (Gamal et al, 2011, Gatignon et al., 2002). For analytical purposes, all these stages require 
narrative descriptions, quantitative and qualitative measures and assessment or evaluation.

The purpose of the analytical framework for combinative innovation is to verify the degree and nature of combinations and the interactions between the stages of innovation and methods of combination. The framework introduced here is based on the five modes in Table 1. The framework is a matrix that consists of each stage of innovation as the row and the modes of combination as the column. The characteristics of combination modes and the role of each mode are identified with the interactions with the stages of the innovation.

Instead of a thorough treatment of these, the paper analyzes a case of technological (product and process) innovation according to the framework. The case is the CDMA digital mobile phone development of Samsung. Further elaboration of the analytical framework is done through the case study. The case study in the following section covers all stages of innovation and five modes of combination, but, depending on the relative importance, some of them are discussed in more detail whereas others are sketched only.

\section{Case Analyses}

\subsection{Purpose of the Case Analysis}

The case analysis in this paper attempts to show how combinative innovations are adopted and implemented to further elaborate and show the usefulness of the framework introduced in the previous section. We are living in an age of convergence of technologies and business. More and more technological convergences are emerging every day in the areas of IT, BT, NT, $\mathrm{ET}$, and so on. Convergence of different industries is not uncommon. Among these, digital convergence ${ }^{1}$ is the representative phenomenon. Although most innovations share the nature of combinative innovation, digital convergence is a demanding area for the application of the approach and the analytical framework introduced in the previous section. Especially, Samsung which chose digital convergence as one of the key slogans offers very interesting and successive cases of combinative innovations rendering plenty of implications.

\footnotetext{
${ }^{1}$ Wikipedia says, "Digital convergence refers to the convergence of four industries into one conglomerate, ITTCE (Information Technologies, Telecommunication, Consumer Electronics, and Entertainment). This provides new, innovative solutions to consumers and business users. Based on digital technologies and digitized content it encompasses converged devices (such as smart phone, laptops, internet enabled entertainment devices and set top boxes), converged applications (e.g. music download on PC and handheld) and converged networks (IP networks)." (October 28, 2012)
} 
For the case of the CDMA digital mobile phone development of Samsung this paper shows what kinds of combination modes for combinative innovations were chosen by the decision makers. It is also concerned with factors such as business environment and strategy, management, business culture and organization, characteristics of markets, goals of innovations, available resources, opportunities, and above all characteristics of technological knowledge that affect innovations. Identifying outcomes and effects of innovations are important parts of the case study. Ideally, the paper should show that there are patterns of combinative innovations over time. The patterns, if any, are formed by long-term changes and the evolution of abovementioned factors. This means, if there are significant changes or differences in some of the factors and conditions, a firm may change the pattern of combinative innovation. Because the case mainly deals with the CDMA digital mobile phone development of the 1990s, finding patterns is not attempted.

\subsection{The Mobile Phone Market in Korea before the CDMA Digital Phone}

The mobile telecommunication service started from 1984 in Korea. (Lee and Han, 2002). The service was offered by the Korea Mobile Telecommunications Service Company (later, renamed as KMT), which was a subsidiary of a public corporation, KET (now KT). This was the $1 \mathrm{G}$ era based on analogue technology and Korea depended on foreign companies in terms of markets and technologies.

Mobile phones made by Korean firms began to appear in the market in 1991, but their performance was not impressive at all ${ }^{2}$ as shown in Table 2. Although Samsung Electronics, Hyundai Electronics, and Kumsung Information and Communications (later LG) produced mobile phones, Motorola dominated the market with a share of around 50\%. Samsung was in the second position with the market share of 30\% in 1995. Korean producers imported most core components so their own technological competence was low at that time.

\footnotetext{
${ }^{2}$ In fact Samsung developed its first mobile phone, SH-100 with a poor market performance. (Lee and Lee, 2004)
} 
Table 2 Market share of handset makers in the Korean market

\begin{tabular}{|c|r|r|r|r|r|}
\hline$(\%)$ & \multicolumn{1}{|c|}{1991} & \multicolumn{1}{c|}{1992} & \multicolumn{1}{c|}{1993} & 1994 & 1995 \\
\hline Motorola & 42.0 & 45.4 & 57.4 & 51.9 & 51.9 \\
\hline Samsung & 20.0 & 19.4 & 14.0 & 19.7 & 30.0 \\
\hline Kumsung & 9.2 & 8.6 & 5.0 & 4.0 & 3.8 \\
\hline Hyundai & 9.4 & 7.8 & n/a & 1.3 & 0.3 \\
\hline Others & 19.4 & 18.8 & 23.6 & 23.1 & 14.0 \\
\hline Total & 100.0 & 100.0 & 100.0 & 10.0 & 100.0 \\
\hline
\end{tabular}

Source: Lee and Han (2002) (Originally, ETRI Report, 1997, 140)

\subsection{The CDMA Technology Development Project}

The Korean government realized the importance of the telecommunication industry and decided to secure its own networks and basic technologies. In the late 1980s, the world was watching the emerging $2 \mathrm{G}$, digital mobile telecommunication system. In 1989 the Ministry of Communication launched a project for developing an original mobile telecommunication system. The major player in the project was the research institute established by the government in 1985, the Electronics and Telecommunication Research Institute (ETRI). The institute played the central role by managing the whole project. Several private domestic firms, such as Samsung Electronics, Kumsung Information and Communications, Hyundai Electronics, and Maxon Electronics were invited to participate in the project. Qualcomm, then a small venture company in America, also joined the project as the counter partner to ETRI and provided the generic technology of CDMA.

Although Qualcomm had the generic technology of CDMA, it did not have the competence in switching systems and mass manufacturing. ETRI was a suitable partner to Qualcomm. As a result, ETRI and Qualcomm made a Joint Development Agreement in 1991. The responsibilities of Qualcomm were the design of the whole CDMA system and technological consultation. They also agreed to allow Korean firms to participate in the project. (Lee and Han, 2002). The project ended in 1996 when Korea successively commercialized first in the world the CDMA telecommunication system including the CDMA mobile phone. As shown in Figure 1, the project was a consortium of institutes and domestic and foreign private firms, sponsored by the government. 


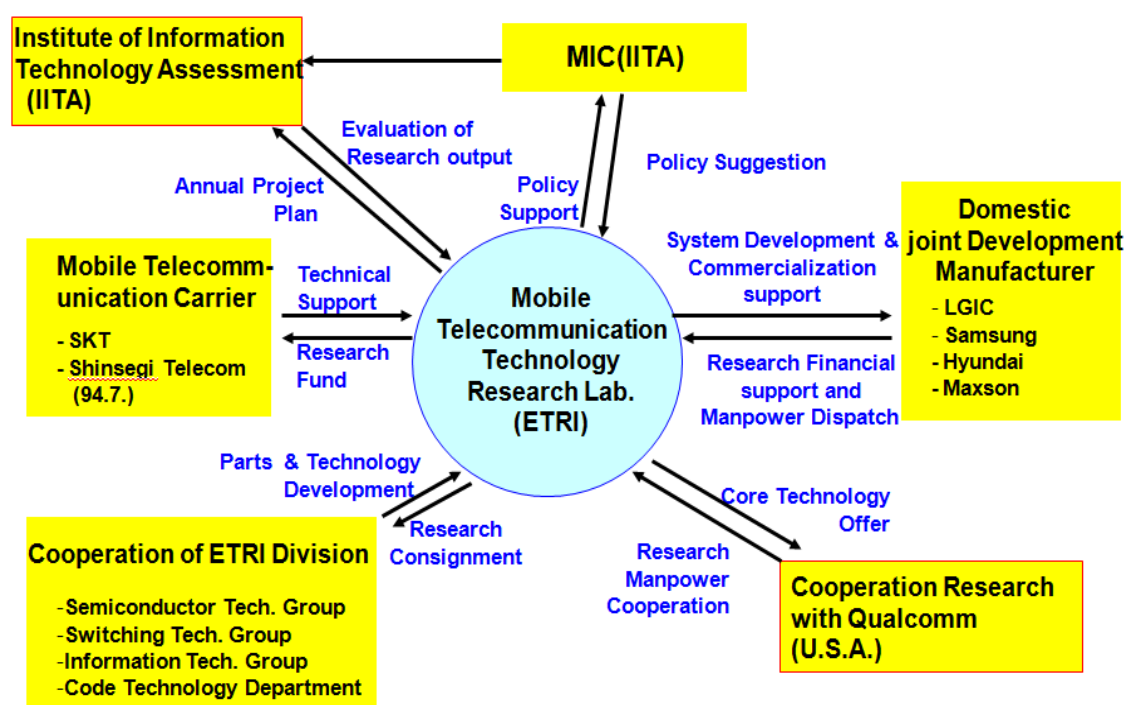

Source: Jun (2003)

Figure 1 CDMA system development consortium and networking

Table 3 shows the roles of manufacturers in the development of the CDMA cellular phone, working closely with ETRI. Although their main role was developing the new mobile phone, they also participated in the system development. ETRI assisted and guided their development efforts and activities.

Table 3 Roles of manufacturers in the development CDMA for cellular

\begin{tabular}{|l|l|}
\hline \multicolumn{1}{|c|}{ Sub-systems } & \multicolumn{1}{c|}{ Participants } \\
\hline Mobile phones & $\begin{array}{l}\text { Samsung Electronics, Kumsung Information and } \\
\text { Communication, Hyundai Electronics, Maxon } \\
\text { Electronics }\end{array}$ \\
\hline Base stations & $\begin{array}{l}\text { Kumsung Information and Communication, } \\
\text { Hyundai Electronics }\end{array}$ \\
\hline Control stations & Samsung Electronics, Hyundai Electronics \\
\hline Exchange stations & $\begin{array}{l}\text { Samsung Electronics, Kumsung Information and } \\
\text { Communication }\end{array}$ \\
\hline $\begin{array}{l}\text { Registers of subscribers' } \\
\text { location }\end{array}$ & Samsung Electronics, Hyundai Electronics \\
\hline
\end{tabular}

Source: Lee and Han (2002) 


\subsection{Innovation Stages and Factors Affected Combination}

Among those private firms that participated in the consortium, Samsung was most active. Table 4 shows the major feature of Samsung's CDMA cellular phone development. The table also summarizes the activities and characteristics by each mode of combination in the analytical framework introduced above.

Table 4-1 Innovation activities for CDMA digital phone development of Samsung

\begin{tabular}{|c|c|c|}
\hline & Activities/Characteristics & Remarks \\
\hline $\begin{array}{l}\text { Period and } \\
\text { highlights }\end{array}$ & $\begin{array}{l}\text { - Participated in the Mobile Communication System (CDMA) } \\
\text { Development Consortium in 1989-1996. } \\
\text { - Korean government initiated the consortium which consisted of ETRI, } \\
\text { Qualcomm, several domestic electronics companies. } \\
\text { - An American venture company Qualcomm joined in the development } \\
\text { with its generic technology, CDMA. } \\
\text { - Samsung's first 1G (analogue) mobile phone, SH-10o was introduced in } \\
\text { 1988, but performed unsatisfactory. } \\
\text { - Samsung's first 2G (digital) mobile phone was introduced in } 1996 \text { and } \\
\text { successively, SCH-110o. } \\
\text { - In } 1997 \text { Samsung achieved a 57\% of domestic market. }\end{array}$ & $\begin{array}{l}\text { - Samsung and other } \\
\text { three manufacturers } \\
\text { participated in the } \\
\text { consortium from } 1993 .\end{array}$ \\
\hline $\begin{array}{l}\text { Dyna } \\
\text { comb }\end{array}$ & $\begin{array}{l}\text { - Instead of } 1 \mathrm{G} \text { 'analogue' phone, developing a new } 2 \mathrm{G} \text { 'digital' phone } \\
\text { was the goal. } \\
\text { - The CDMA cellular phone system was first commercialized by Korea } \\
\text { in } 1996 \text { as the result of the Consortium's joint R\&D. }\end{array}$ & $\begin{array}{l}\text { - Not revolutionary, } \\
\text { but architectural } \\
\text { innovation }\end{array}$ \\
\hline $\begin{array}{l}\text { Open } \\
\text { combination }\end{array}$ & $\begin{array}{l}\text { - Although CDMA phone was based on competition among the four } \\
\text { companies, utilization of external technologies were essential. } \\
\text { - The direction of technologies between Samsung and outsiders was } \\
\text { mostly of absorptive nature. }\end{array}$ & $\begin{array}{l}\text { - E.g. Qualcomm's } \\
\text { generic CDMA } \\
\text { technology } \\
\text { - ETRI provided } \\
\text { technologies, } \\
\text { assistance and guide }\end{array}$ \\
\hline $\begin{array}{l}\text { Vertical } \\
\text { combination }\end{array}$ & $\begin{array}{l}\text { - Before the CDMA phone, Samsung already produced several versions } \\
\text { of its } 1 G \text { phone and accumulated technologies in semiconductors } \\
\text { (DRAM), home appliances, TV sets, LCD display and so on. } \\
\text { - Samsung's technological innovation is vertically integrated from the } \\
\text { upstream to the downstream. } \\
\text { - Since the CDMA phone is the end product, vertical combination is } \\
\text { characterized by slightly more of downstream. }\end{array}$ & $\begin{array}{l}\text { - Strong vertical } \\
\text { combination gives } \\
\text { Samsung competitive } \\
\text { advantage over rivals. }\end{array}$ \\
\hline $\begin{array}{l}\text { Functional } \\
\text { combination }\end{array}$ & $\begin{array}{l}\text { - Since the CDMA phone is a new mobile phone }(2 G) \text {, different from } \\
\text { previous } 1 G \text { phone, the innovation is extensive in terms of functions. } \\
\text { - However, some parts were the same as } 1 G \text { phone, but intensive in } \\
\text { quality. }\end{array}$ & $\begin{array}{l}\text { - Many new functions } \\
\text { were added. }\end{array}$ \\
\hline \begin{tabular}{|l|} 
Multiple \\
combination
\end{tabular} & - All $f$ & $\begin{array}{l}\text { - Different teams often } \\
\text { had joint meetings. }\end{array}$ \\
\hline
\end{tabular}


Table 4-2 Innovation activities for CDMA digital phone development of Samsung

\begin{tabular}{|c|c|c|}
\hline Results & $\begin{array}{l}\text { - Samsung's market share in the domestic mobile phone market was } \\
56 \% \text {; Motorola's share was close to } 0 \% \text { in } 2001 . \\
\text { - Samsung became world No.1 smart phone producer in } 2012 \text {. } \\
\text { - Samsung is the No.2 company in terms of patent application to the } \\
\text { US Patent Office. }\end{array}$ & $\begin{array}{l}\text { - Samsung is one of } \\
\text { the world leaders in } \\
\text { digital technology. }\end{array}$ \\
\hline
\end{tabular}

Source: Compiled by the author, based on various documents and references ${ }^{3}$.

The detailed explanation of the contents of the table needs enormous space. As an example, Figure 2 is shown here for the background of the open combination and vertical combination. As shown in the figure, a mobile phone consists of a lot of parts and components, hence technologies. This fact requires two considerations from the viewpoint of the innovator. How many of and what existing parts and components should come within the firm and what and how many should be acquired from outside partners. Samsung already secured some technologies for mobile phone production, and shared technological knowledge with many collaborative partners and suppliers of components. In addition, Samsung is a unique manufacturer in this field, which produces a variety of different IT products such as semiconductors, displays, cameras, and so on. Under the circumstances, Samsung made the choice of vertical combination and open combination.

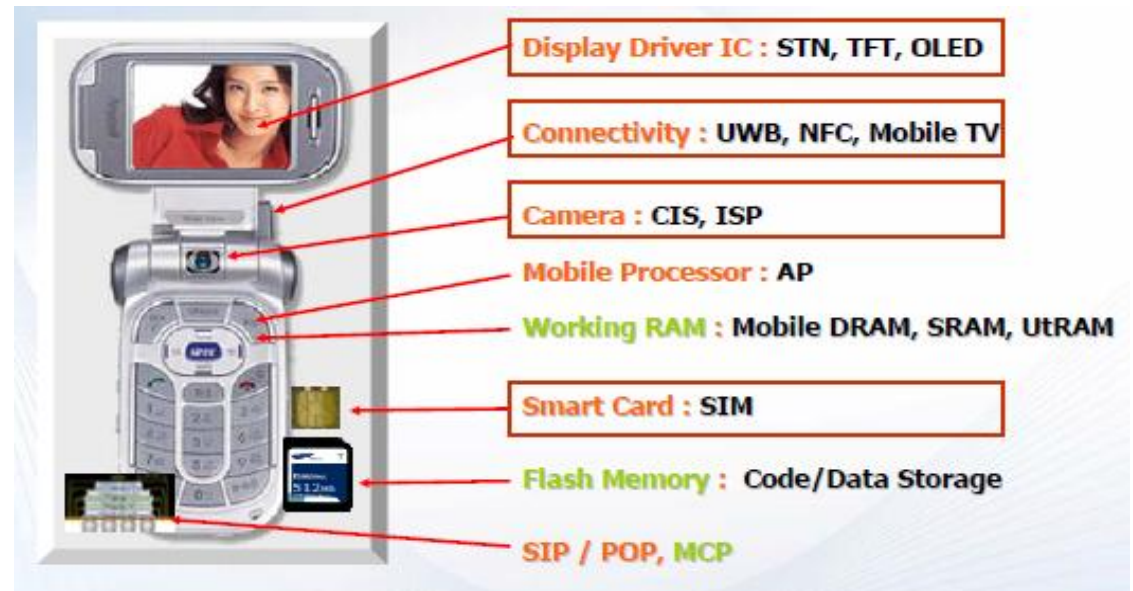

Source: Lee et al. (2008)

Figure 2 Total mobile solution of Samsung

\footnotetext{
${ }^{3}$ Readers more interested in the backup information are recommended to refer to the following references: Kang, Jin Koo (1996), Samsung Economic Research Institute (SERI) (2001), Cho et al. (2005), Lee, Sung Ho et al. (2008).
} 


\subsection{Choice of Modes}

Table 5 summarizes the choice of combination modes and resulting characteristics. The CDMA-based mobile phone development of Samsung between 1990 and 2004 can be characterized as the following combinative innovation.

First, the innovation was dynamic because an entirely new technology, the CDMA system unknown to the company in the past, was developed for the future. Although the company already experienced and acquired TDX technology capacity, and manufacturing capacity of the analogue-based cellular phone, the CDMA-based mobile phone was entirely new for the future. Even the future success was not clear at that time and highly risky. It is a typical architectural innovation that needed dexterous decisions and was fundamentally oriented towards exploration. Thus, the dynamic combination mode was dominated by exploration. For the dynamic combination, Samsung had to give more weight to the exploration of the new mobile system, which was an entirely new $2 \mathrm{G}$ digital system to Samsung and others. The CDMA technology never had been commercialized in the world at that time when Samsung and the consortium started to commercialize it (Park et al., 2011).

Table 5 Choice and characteristics of CDMA cellular phone development

\begin{tabular}{|l|l|l|l|}
\hline \multicolumn{1}{|c|}{ Mode } & \multicolumn{1}{|c|}{ Direction } & Importance & \multicolumn{1}{c|}{ Remarks } \\
\hline $\begin{array}{l}\text { Dynamic } \\
\text { combination }\end{array}$ & $\begin{array}{l}\text { Exploitation } \\
<<<<\text { exploration }\end{array}$ & Critical & $\begin{array}{l}\text { - CDMA was an entirely new system and the } \\
\text { beginning of future versions. }\end{array}$ \\
\hline $\begin{array}{l}\text { Open } \\
\text { combination }\end{array}$ & $\begin{array}{l}\text { Absorptive } \\
>>>\text { distributive }\end{array}$ & Substantial & $\begin{array}{l}\text { - The generic CDMA technology was transferred } \\
\text { from Qualcomm } \\
\text { - ETRI provided with important technological } \\
\text { knowledge and helped problem solving in R\&D. } \\
\text { - Participating companies shared technological } \\
\text { knowledge, if necessary. }\end{array}$ \\
\hline $\begin{array}{l}\text { Vertical } \\
\text { combination }\end{array}$ & $\begin{array}{l}\text { Upstream } \\
<\text { downstream }\end{array}$ & Substantial & $\begin{array}{l}\text { - Having secured successful IT and electronics area } \\
\text { is Samsung's strength for digital convergence } \\
\text { - However, because of the new end product, } \\
\text { downstream technologies were emphasized. }\end{array}$ \\
\hline $\begin{array}{l}\text { Functional } \\
\text { combination }\end{array}$ & $\begin{array}{l}\text { Intensive } \\
<<\text { extensive }\end{array}$ & Critical & $\begin{array}{l}\text { - Already secured technologies should improve } \\
\text { quality and technologies for new functions should } \\
\text { be developed for the CDMA cellular phone. }\end{array}$ \\
\hline $\begin{array}{l}\text { Multiple } \\
\text { combination }\end{array}$ & Synergic & $\begin{array}{l}\text { Main } \\
\text { strategy }\end{array}$ & $\begin{array}{l}\text { - Digital convergence is Samsung's goal, which } \\
\text { required the combinative innovation with synergic } \\
\text { multiple combination. }\end{array}$ \\
\hline
\end{tabular}

Note: The number of symbol > or < indicates the degree.

Second, for the open combination the company had to depend more on outsiders such as ETRI, Qualcomm, and other competitive participants in the 
consortium. Especially, ETRI assisted the participants including Samsung by technological knowledge transfer. One interesting feature of this joint R\&D is that among participants there was lively information sharing and feedback. Another fact is that all those companies had been developing their own mobile telephone system respectively, even if they jointly participated in the CDMA consortium. This implies that they were in competition with each other so that sharing resources and information was limited. The availability and utilization of own capabilities and resources were crucial for individual company's competitiveness. Thus the open combination mode was largely in absorptive nature rather than distributive (sharing).

Third, Samsung already secured other electronics technologies such as semi-conductors, TV sets, micro-oven, and white-color electronics. Also its existing sub-contract system was expanding. As newer versions of CDMA mobile phones were developed later, both upstream and downstream combinations became important so that it is rather difficult to capture the characteristics of the vertical combination mode by one-sided orientation. However, considering the rapid introduction of new versions, it is safe to say that the speed and degree of downstream (i.e. new products) orientation were slightly more weighted.

Fourth, when Samsung started the CDMA mobile phone business, the company gave more R\&D efforts for introducing various new technologies rather than improving already existing or secured technologies. Samsung started its R\&D with the capability from the earlier TDX development. However, the company needed the generic technology about the Korean CDMA system from ETRI (who jointly developed it with Qualcomm). The company concentrated on the development and commercialization phase. More new functions should be added than improving already secured technologies, although the latter activities were also needed. This observation is confirmed by successive introduction of new models and expansion to the GSP mobile telephone business. The mode of functional combinations obviously was of extensive nature.

Fifth, of the combinative mode, Samsung and many big companies usually use all four modes of combination simultaneously, especially for big R\&D architectural innovation. However, the way of managing these four modes simultaneously is different among different innovation projects and companies. For the CDMA system development, as discussed so far, Samsung used all those four modes simultaneously in order to maximize synergy and shorten development process (Goldman, 2012). "Speed" is the managerial motto for innovation. For speedy innovation, a multiple combination of sub-modes of combinations with parallel and interactive operation is the key. Hence, the multi combination mode of Samsung was obviously of synergic nature. 


\section{Evaluation}

\subsection{Technological Contributions}

The most difficult part of the case study is the evaluation of the combination innovation results, because evaluation requires elaborated measure. However, a preliminary exercise, even though it may be subjective, would be helpful to see the usefulness of the analytical framework introduced in this paper. Table 6 summarizes the author's own evaluation of technological contributions of the case. The selected four evaluation categories are technology (R\&D) capability building, acquisition of new technologies, improvement of existing technologies, and increase in technological networks. ${ }^{4}$ Although the evaluations are based on various documents and several interviews, they are inevitably subjective. Thus, they are by no means claimed scientific, but for illustrative purpose only. The discussion on the evaluation is in the order of contribution categories.

Table 6 Technological contributions by mode of combination

\begin{tabular}{|l|c|c|c|c|}
\hline & $\begin{array}{l}\text { Overall tech. } \\
\text { capability } \\
\text { building (R\&D) }\end{array}$ & $\begin{array}{l}\text { Acquisition } \\
\text { of new tech. }\end{array}$ & $\begin{array}{l}\text { Improving } \\
\text { existing tech. }\end{array}$ & $\begin{array}{l}\text { Expanding } \\
\text { tech. network }\end{array}$ \\
\hline $\begin{array}{l}\text { Dynamic } \\
\text { combination }\end{array}$ & $* * *$ & $* * *$ & $*$ & $* *$ \\
\hline $\begin{array}{l}\text { Open } \\
\text { combination }\end{array}$ & $* *$ & $* * *$ & $*$ & $* * *$ \\
\hline $\begin{array}{l}\text { Vertical } \\
\text { combination }\end{array}$ & $* *$ & $* *$ & $* *$ & $*$ \\
\hline $\begin{array}{l}\text { Functional } \\
\text { combination }\end{array}$ & $* * *$ & $* * *$ & $* *$ & $* *$ \\
\hline $\begin{array}{l}\text { Multiple } \\
\text { combination } \\
\text { (Sum) }\end{array}$ & $* * *$ & $* * *$ & $* *$ & $*$ \\
\hline
\end{tabular}

Note: The number of symbol * indicates the level of contribution.

The case of Samsung's CDMA phone development shows that the contributions of each mode of combination to enhancing the company's mobile phone-related technological capability are positive in general, but the relative contributions differ. First, the contributions to the overall technological capability building were outstanding because Samsung started

\footnotetext{
${ }^{4}$ Of course, other categories can be considered. Evaluation and measure for combinative innovation are the issues to be further explored in coming research.
} 
with a weak basis but it became a powerhouse of CDMA-based technologies and later GSM technologies from the CDMA technology accumulation and R\&D experiences. If Samsung had not the CDMA development experience, the present day Samsung which is an arch rival to Apple would not have existed.

Although the Korean government and ETRI decided to adopt the CDMA system as the national standard, a serious challenge was waiting. When Korea was considering the CDMA system, Korean research institutes and companies including Samsung secured only limited technological capabilities through the TDX development experience in the 1980s. These capabilities were not sufficient to develop the CDMA system technologies. Korean institutes and companies had neither knowledge nor accumulated technological capability about the CDMA system. Under the circumstance, it was inevitable to form a consortium among ETRI, Qualcomm, and Korean companies. As reviewed earlier, the approach was a great success and participants reaped a technological leapfrogging.

In the case of Samsung, a dynamic combination that was explorative made the greatest contribution to technological capability building because the strategic choice of exploring the new technology system turned out to be a great success. Accordingly, the extensive functional combination also made a great contribution. Considering the characteristics of the modes, the relative contributions of the open combination and the vertical combination were also high, but less than the other two modes. Adding all these, the contribution of the multiple combinations is evaluated very high.

Acquisition of new technologies can be evaluated by the proxy of patent acquisition. As ETRI and participant companies accumulated technological capabilities, patent application increased from 1994. As of 2004 February, Samsung registered 102 patents in the U.S., ETRI registered 35 patents, LG registered 25 patents, and Hyundai registered 23 patents. This U.S. patent registration status of the participants in the CDMA system development and commercialization project confirms that Samsung led the patenting activity. Samsung's active patenting reflects its technological competitiveness and strategic movement for the future. The patenting activity and technological competitiveness can also be measured by the number of domestic patents as a proxy. As of February 2004, Samsung registered 426 domestic CDMA-related patents, LG registered 345 patents, ETRI registered 293 patents, and Hyundai registered 49 patents (Um and Lee. 2006). Since the acquisition of patents is the result of technological development and all modes of combinations contributed to this result, there is less difference in the relative contributions of each mode.

The CDMA system development by Samsung contributed to the acquisition of new technologies rather than improving existing technologies, 
because it was oriented towards an entirely new digital mobile phone development. Thus, each mode's contribution to improvement of existing technologies was less impressive.

The CDMA development consortium was a joint R\&D system among industry and the research community. There was joint R\&D between ETRI and Qualcomm. Then there was joint R\&D among local companies, namely, Samsung, LG, Hyundai, Maxon, etc. The role of ETRI was central and vital. It provided the private sector with generic CDMA technology, which it acquired through joint R\&D with Qualcomm. ETRI guided and coordinated the R\&D activities of companies. Especially, it collected $R \& D$ information from individual companies and disseminated among companies. In fact, not only big companies such as Samsung, LG and Hyundai, but also small and medium companies such as Maxon, Appeal Telecom, Standard Telecom, Hanwha Telecom, Haitai, etc. also participated in the CDMA development. Big companies jointly developed parts and components with "cooperation companies." The networking among participant companies became very active as the development went on (Um and Lee. 2006).

This kind of approach based on consortium and joint R\&D contributed to the widening network among participants. Samsung got benefits from the network. Among the combination modes, open combination made greatest contribution to networking.

\subsection{Economic Contribution}

The usefulness of the framework can be further demonstrated by Table 7 , which shows the evaluation of economic contributions. Also four categories are chosen for evaluating economic contributions. The first category for economic contribution is the contribution to cost reduction. Developing a new digital mobile telephone system has several difficulties. First, it requires a huge amount of research funds. Second, usually it takes a long period. Third, it is exposed to high risk of failure. Thus, companies in the private sector were hesitant to participate in the development process and the government shared a substantial amount of the total research expenditure. ${ }^{5}$ To the extent of the government sharing the development fund, the participant companies including Samsung could reduce the cost. In addition, Samsung could reduce the development cost further by choosing proper combination modes. The open combination and the vertical combination that the company chose made relatively high contributions to cost saving.

\footnotetext{
${ }^{5}$ The CDMA system development was undertaken from 1989 to 1996 with the total R\&D expenditure of 99.6 billion KRW. The Korean government shared 53.4 billion KRW, two Korean telecommunication companies shared 21.9 billion KRW, and four Korean companies shared 23.5 billion KRW.
} 
However, there was another problem which brought cost increase. According to the view of Um and Lee (2006), the CDMA system development was focused on development and application research so that Korean companies could not overcome the weakness of R\&D capability for generic technology. At that time Samsung was not an exception. Local companies had to pay running royalty of $5.25 \sim 6.5 \%$ to Qualcomm for 15 years.

Table 7 Economic contributions by mode of combination

\begin{tabular}{|l|c|c|c|c|}
\hline & $\begin{array}{c}\text { Cost } \\
\text { reduction }\end{array}$ & $\begin{array}{c}\text { Sales and profit } \\
\text { increase }\end{array}$ & $\begin{array}{c}\text { Market share } \\
\text { increase }\end{array}$ & $\begin{array}{c}\text { Brand value } \\
\text { increase }\end{array}$ \\
\hline $\begin{array}{l}\text { Dynamic } \\
\text { combination }\end{array}$ & $*$ & $* * *$ & $* * *$ & $* * *$ \\
\hline $\begin{array}{l}\text { Open } \\
\text { combination }\end{array}$ & $* * *$ & $* *$ & $\mathrm{n} / \mathrm{a}$ & $* *$ \\
\hline $\begin{array}{l}\text { Vertical } \\
\text { combination }\end{array}$ & $* *$ & $* *$ & $\mathrm{n} / \mathrm{a}$ & $\mathrm{n} / \mathrm{a}$ \\
\hline $\begin{array}{l}\text { Functional } \\
\text { combination }\end{array}$ & $*$ & $* * *$ & $* * *$ & $* * * *$ \\
\hline $\begin{array}{l}\text { Multiple } \\
\text { combination } \\
\text { (Sum) }\end{array}$ & $* *$ & $* * *$ & $* * *$ & $* * *$ \\
\hline
\end{tabular}

Note: The number of symbol * indicates the level of contribution.

Adding up all these decreases and increases, the net cost reduction should be evaluated in comparison with alternatives in general and the GSM based mobile phone in particular. Since the latter was later developed in addition to the CDMA phones by Samsung, it is almost impossible to assess exactly the net cost reduction of the CDMA case only. Here, the evaluation is only referring to government funding. Because it was based on the condition to joint R\&D activities, it is directly related to the open combination and the contribution of this mode to cost reduction is the highest among all modes.

The second category of economic contributions is to sales and profit increase. As shown in Table 8 for the Korean market, the total revenue and profit of Samsung in 2003 was 43.6 trillion KRW and 7.2 trillion KRW, respectively. Among divisions, the Telecommunications Division ranked the second highest position with a share of $32.6 \%$ and $37.6 \%$, respectively. Telecommunications Division deals with network equipment as well as mobile phones. However, mobile phone business accounts for $90 \%$ of total sales for the Telecommunications division. All modes of combinations contributed to the increase in sales and profit, but the dynamic combination and the functional combination contributed more, because these increases mainly came from the novelty of the CDMA mobile phones. 
Table 8 Samsung's sales and profits by division (2003)

(Unit: 10 billion KRW, \%)

\begin{tabular}{|l|r|r|r|r|}
\hline \multicolumn{1}{|c|}{ Division } & \multicolumn{2}{c|}{ Sales } & \multicolumn{2}{c|}{ Operating Profit } \\
\hline Device Solutions & 17,904 & 41.1 & 4,507 & 62.7 \\
\hline Telecommunication & 14,202 & 32.6 & 2,703 & 37.6 \\
\hline Digital Media & 7,745 & 17.8 & 145 & 2.0 \\
\hline Digital Appliance & 3,406 & 7.8 & -111 & -1.5 \\
\hline Others & 352 & 0.8 & -51 & -0.7 \\
\hline Total & 43,609 & 100.0 & 7,193 & 100.0 \\
\hline
\end{tabular}

Source: Samsung Electronics, 2003 Annual Report, www.sec.co.kr

Samsung's position in terms of sales and profit in the world mobile phone position is shown in Table 9. In 2002, Samsung was third after Nokia and Motorola, but in 2003 it ranked second to Nokia. A caveat is needed. The numbers of Samsung in the table include the revenues and profits of GSM produced by Samsung, although the amounts were much smaller at that time.

Table 9 Sales and profits of major mobile phone makers in the world

\begin{tabular}{|c|c|c|c|c|}
\hline Company & Unit & Revenue and profit & 2002 & 2003 \\
\hline Nokia & (EURm) & $\begin{array}{r}\text { Revenues Operating } \\
\text { Profit } \\
\text { (Profit margin) }\end{array}$ & $\begin{array}{r}23,211 \\
5201 \\
(22.4 \%)\end{array}$ & $\begin{array}{r}23,618 \\
5,486 \\
(23.2 \%) \\
\end{array}$ \\
\hline Motorola & $(\$ \mathrm{~m})$ & $\begin{array}{r}\text { Revenues Operating } \\
\text { Profit } \\
\text { (Profit margin) }\end{array}$ & $\begin{array}{r}11,174 \\
503 \\
(4.5 \%) \\
\end{array}$ & $\begin{array}{r}11,009 \\
479 \\
(4.4 \%) \\
\end{array}$ \\
\hline Sams & (KRWb) & $\begin{array}{r}\text { Revenues Operating } \\
\text { Profit } \\
\text { (Profit margin) }\end{array}$ & $\begin{array}{r}10,616 \\
2,705 \\
(25.5 \%)\end{array}$ & $\begin{array}{r}12,881 \\
2600 \\
(20.2 \%) \\
\end{array}$ \\
\hline Siemens & (EURm) & $\begin{array}{r}\text { Revenues Operating } \\
\text { Profit } \\
\text { (Profit margin) } \\
\end{array}$ & $\begin{array}{r}2,361 \\
93 \\
(3.9 \%) \\
\end{array}$ & $\begin{array}{r}4,651 \\
38 \\
(0.8 \%) \\
\end{array}$ \\
\hline LG & (KRWb) & $\begin{array}{r}\text { Revenues Operating } \\
\text { Profit } \\
\text { (Profit margin) }\end{array}$ & $\begin{array}{r}3,357 \\
434 \\
(10.2 \%)\end{array}$ & $\begin{array}{r}5,119 \\
250 \\
(4.9 \%)\end{array}$ \\
\hline
\end{tabular}

Source: Lee and Lee. 2004. (Originally, Daeshin Economic Research Institute, March 3, 2004).

Third category is market share. As shown in Table Figure 2, Samsung achieved 56\% share of the domestic CDMA cellular market in 1997. By 1999 Samsung already secured the number one position in the worldwide CDMA market. However, the worldwide GSM market having 70\% market share was much larger than the CDMA market in the world. Samsung also tried to 
penetrate the GSM market. Samsung's first GSM model, SGH-200, was made for European customers. But it was not as good as the company's CDMA phone. It was much later that Samsung gained a substantial market share in the worldwide GSM market (Quelch and Harrington, 2008).

The dynamic combination and the functional combination made higher contributions to the market share increases. The reason is due to the nature of the innovation, which was to develop an entirely new product and it was a great success. This evaluation is similar to the contributions to sales and profits.

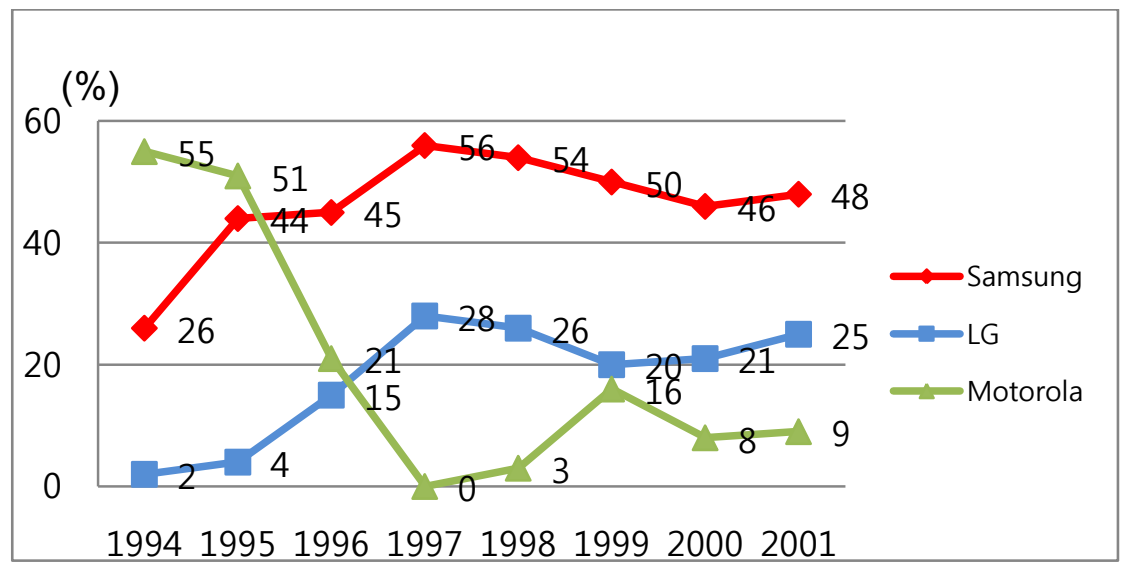

Note: 2001, for the first six months

Source: SERI (2001).

Figure 3 Trends of market share by major handset maker in Korea

The last category is the contribution to brand value. Samsung's brand value, assessed by Interbrand was 6.4 billion US dollars in 2001 and increased to 8.3 billion US dollars in 2002. Samsung's world rank jumped from No. 42nd to No. 34th in a year (Samsung Electronics, 2012). The evaluation of contribution by each combination mode is similar to the evaluation for market share, because of the same reason.

\section{Implications and Conclusion}

As an extension of Schumpeter's original concept of innovation, this paper introduced the concept of combinative innovation and elaborated the nature and function of combination by five modes. These are dynamic combination mode, open combination mode, vertical combination mode, functional combination mode, and multiple combination mode. 
The main findings and implications of the case study are as follows:

First, there are different modes of combinations for combinative innovation and these modes are distinguishable. A combinative innovation requires different composition of the modes combining contrasting factors differently.

Second, for an architectural innovation for a new product, the dynamic combination mode and the functional combination mode seem to be more active and important.

Third, in the age of convergence, synergic multiple combinations seem to be adopted. If a speedy innovation is needed, this tendency would be dominant. ${ }^{6}$

Fourth, more rigorous measures for identifying mode characteristics and evaluating contributions of each mode are necessary (e.g. Gamal et al., 2011; Gatignon et al., 2002).

Although not discussed further, there may be more interesting implications in terms of comparison of the new concepts and modes of combination introduced in this paper and other existing concepts or types of innovation. For example, recently, open innovation (Lakhani, 2012) is a popular jargon in innovation. Many claims have been made that it is the dominant mode of innovation in this era of complex and speedy technological innovation. However, this case study, although it is for only one company case, shows that a firm uses several different modes of combinations and open innovation is only one of them.

The case analysis indicates that the concept of combinative innovation and modes of combination render a useful analytical tool for identifying the patterns of innovation and on how to formulate innovation strategies as well as implementation of combinative innovation. In this age of convergence, seldom is a single mode of combination adopted. Instead, several modes are adopted simultaneously so that multi-dimensional or multi-layered combinations are typical. The case study of Samsung's first CDMA (2G) mobile phone development shows that the dynamic combination mode and the functional combination mode are relatively more important for an architectural innovation.

In order to derive systematic patterns of combinations and enhance the predictability of the approach, further elaboration of the analytical framework and more case studies are needed. Especially identifying compositions of each combination and evaluation of the outcomes and performance require proper criteria and measures. More theoretical and empirical research is called for.

\footnotetext{
${ }^{6}$ This is a rough conjecture in this study. For a clearer finding for this requires a comparison of several cases
} 


\section{References}

Alkaersig, L. et al. (2012) Not all combinations are created equal - how the technological and combinative capabilities of the firm affect innovation value, paper presented at the DRUID 2012 conference, June 19-21, Copenhagen, Denmark.

Bogers, M. and West, J. (2011) Managing distributed innovation: strategic utilization of open and user innovation. Creativity and Innovation Management, 21(1), 61-75.

Cho, H. et al. (2005) Samsung Electronics, the digital conqueror, Seoul: Maekyung Publishing. (in Korean)

ETRI (1997) A Study on the prospect and strategy for the next generation mobile telecommunication related industries.

Gamal, H. et al. (2011) How to measure organization innovativeness?, Technology Innovation and Entrepreneurship Center.

Garcia, R. and Calantone, R. (2002) A critical look at technological innovation typology and innovativeness terminology: a literature review, The Journal of Product Innovation Management, 19(2), 110-132.

Gatignon, H. et al. (2002) A structural approach to assessing innovation: Construct development of innovation locus, type, and characteristics, Management Science 48(9), 1103-1122.

Gil, Y. et al. (2001) Integration model of technology internalization modes and learning strategy: globally late starter Samsung's successful practices in South Korea, Technovation, 23(4), 333-347.

Goldman, F.L. (2012) The dynamics of organizational knowledge: a framework for innovation, DRUID Academy.

Jun, Y. (2003) Study on ICT system technology development strategy for late comer firms in the Asia-Pacific region, presentation material at the APT Study Group, 24SG-SG3-04-3.4-2, Male, Maldives.

Kang, J.K. (1996) The legend and secret of Samsung Electronics. Seoul: Koryowon. (in Korean)

Kogut, B. and Udo Z. (1992) Knowledge of the firm, combinative capabilities, and the replication of technology, Organization Science, 3(3), 383-396.

Lakhani, K.R. et al. (2012) Open innovation and organizational boundaries: the impact of task decomposition and knowledge distribution on the locus of innovation, Harvard Business School Press.

Lee, B.Y and Lee, S.J. (2004) Case study of Samsung's mobile phone business, KDI School Working Paper Series.

Lee, H. and Han, S.Y. (2002) The evolution of the national innovation system in the Korean mobile telecommunication industry, Communications \& Strategies. 48, 4th Quarter, 161-186.

Lee, S.H. et al. (2008) Evolution of the digital mobile phone industry and changes in competition structure, SERI. (in Korean)

Park, H. et al. (2011) A spiral process model of technological innovation in a developing country: the case of Samsung, African Journal of Business Management, 5, 5162-5178. 
Quelch, J. and Harrington, A. (2008) Samsung Electronics Company: global marketing operations, Harvard Business School.

Ramachandran, I. and Lengnick, H.C. (2012) Toward a dynamic view of organizational ambidexterity: promoting a sense of balance and contingency, University of Texas at San Antonio, College of Business Working Paper Series, WP \# 0018MGT-199-2012.

Rasmussen, L. (2012) Optimizing open innovation with Nokia as case, Aarhus School of Business, March.

Samsung Economic Research Institute (SERI) (2001) Implications of CDMA success legend, CEO Information 326. (in Korean)

Samsung Electronics Co. (2012) Wireless market trends, http://www.samsung. com/ sec/aboutsamsung/file/ir/irevent/conference/lehman_021120.pdf

Schumpeter, Joseph A. (1980) The theory of economic development, London: Oxford University Press. (First German edition, 1934.)

Um, C. and Lee, J. (2006) Innovation strategy of mobile-industry in Korea - the case study of CDMA, Korean Local Government Studies, 6(2).

Wang, X.J. and Peng, J.S. (2008) The evolution of combinative capabilities and the cultivation of indigenous innovative capabilities: a case from CTG, IEEE International Conference on Communications, 19-23 May, 5463-5468. 